\title{
THE MORALITY OF SUICIDE TERRORISM AND BOKO HARAM CHALLENGES IN NIGERIA.
}

\author{
Chidiebere Obi \\ Department of Philosophy, Nnamdi Azikiwe University, \\ Awka, Nigeria. \\ $\&$ \\ Uchenna Azubuike Ezeogu \\ *http://dx.doi.org/10.4314/ujah.v14i3.11
}

\section{Abstract}

In the recent years, Nigeria has witnessed the insurgent of terrorist attacks by a group known as Boko Haram. A clear approach to the ideological spring of this Islamic sect has eluded scholarly discussion. One of the major moral challenges with Boko Haram menace has been its method and approach to their struggle. Though there is no clarity with the ideological aims, goals or objectives of this sect, but its acceptance of suicide terrorism in their struggle has become great issues of concern. Boko Haram's suicide terrorism has raised a lot of philosophical questions; what are the grievances that motivated members and sympathizers of Boko Haram? What are the sociopolitical factors that sustain their ideological resonance and operational capability? What are the rationales behind modern religiously inspired terrorism? How did Boko Haram emerge? Is it different from other terrorist groups? What has led to the current outbreak of violence, in the form of Boko Haram? Have conditions somehow worsened in recent years? Is the violence largely a result of a particularly popular radicalizing agent? Does a religion have a right to enjoin acts which are irrational and immoral? Or does the religious person have the converse right-even a God-given right-to analyze the tenets of a 
religion for conformity to reason, and to resolutely discountenance any religious directives which go clearly against reason and ethics? The crux of this work is to philosophically consider the moral implication of suicide terrorism with particular reference to Boko haram.

\section{Introduction}

In the recent time Nigeria has witness a lot of terrorist attacks. This has become a great issue of socio political concern, as many strategies have been drawn by the government to curtail the excesses of the sect responsible for all the attacks. The Islamist group Boko Haram has claimed responsibility of the various terrorist attacks in Nigeria. This scourge of terrorism has been a reality in our everyday existence. Terrorism more or less has become a global phenomenon as no country in the world today directly or indirectly could be said to be free from the catastrophic effect of terrorism. Our first issue of concern is that, man is a rational being and as such there must be rationality for every act of man. The nature of Boko Haram's operation and strategy in terms of execution of their mission has shown a picture of well articulated and properly planned mission. Could it be that, the various attacks by the sect were done by irrational men who lacked sense of reason? The obvious is that deducting from the timing, planning, execution and success of all their various attacks, one cannot but accept that there is rationality behind the whole process.

More so, their mode of terrorist operation has raised serious questions for philosophical reflection. Boko Haram as a terrorist group adopts the method of suicide bombing. This method requires the perpetrator of the terrorist act not to think of escape route in the process of executing his or her mission, but rather to accept death in the course of the mission. What 
The Morality of Suicide Terrorism and Boko Haram Challenges in Nigeria. - Chidiebere Obi \& Uchenna Azubuike Ezeogu

would make a rational being (man) go against the natural law of self preservation? Or could it be that they are irrational? Our earlier position on their modality had proved that it is not possible to deny them of rationality. There seems to be sense of duty and commitment among members of the group. The willingness to sacrifice their lives is clear evidence. The federal government, with the support of the international community, has launched many initiatives to combat the threat posed by Boko Haram. Indeed, considerable amount of money and political capital have been invested in new and continuing programmes to enhance security and contain the threat of Boko Haram in Nigeria. The fundamental questions have not really been looked into. The question; why do people do what they do? What are the motivating factors, the rationale, aims, goals, or reason d'être for their actions.

Suicide terrorism remains a complex phenomenon, as the topic combines so many aspects of human experience including subjects such as: politics, psychology, philosophy, military strategy, and history, to name a few. Terrorism is also emotive both because experiences of terrorist acts arouse tremendous feelings, and because those who see terrorists as justified often have strong feelings concerning the rightness of the use of violence. Without a doubt, terrorism evokes strong feelings whenever it is discussed. A key challenge of understanding terrorism is both acknowledging the moral outrage at terrorist acts, while at the same time trying to understand the rationale behind terrorism. Again, in trying to understand suicide terrorism, the complications associated with finding reliable and valid data on the subject are compounded by the way in which researchers and intelligence analysts fail to address the limitations of their methodology. Suicide terrorism must be understood in terms of social context, and in context of the 
researcher/analyst as a situated being, whose social location and culture affect the way in which they interpret data. For Zuleyka Zevallos (2006), "Suicide terrorism must be understood not only in terms of the cultural context in which it occurs, but also in the context of the researcher as a situated being, whose social location affects the way in which they frame their research questions and interpret their data." Again direct access to the perpetrators of terrorist acts is problematic, either because they are dead, or their identity is unknown, or that they are hiding, or because they are imprisoned and authorities will not grant access, or the perpetrators simple do not wish to talk.

One of the reoccurring questions with respect to this research is, is suicide terrorism justifiable? Suicide terrorism represents a new category of suicide. Why do people become suicide terrorists? To this end, John Horgan (2005) writes that "we cannot hope to examine terrorism outside the context in which it takes place." We are also faced with the problem of interpretation of the concept, as the ubiquitous phrase 'one person's terrorist is another person's freedom fighter' remains evocative. This draws our mind to how interest groups use languages to classify similar acts of violence in different lights in order to further their political interest.

Since man is a rational being, it is quite obvious that, there are motivations which propel one to the act of suicide terrorism. Can religious beliefs, including promise of rewards in the afterlife, further facilitate ones involvement in suicide terrorism? Suicide terrorism can be seen as morally motivated decision making. It is in this light that we shall be looking at the morality of suicide terrorism, with particular reference to 
The Morality of Suicide Terrorism and Boko Haram Challenges in Nigeria. - Chidiebere Obi \& Uchenna Azubuike Ezeogu

Boko Haram case in Nigeria. We shall therefore consider the meaning of suicide terrorism.

\section{What Is Suicide Terrorism?}

Suicide terrorism is a compound word which involves two words; suicide and terrorism. A proper understanding of suicide terrorism lies in the analysis and understanding of these words. Starting with the word terrorism, it is obvious that there is no universally accepted definition of the term. It has no precise definition. The problem with defining terrorism is compounded by the fact that terrorism has recently become a fad word used promiscuously and often applied to a variety of acts of violence which are not strictly terrorism by definition. It is generally pejorative. Some governments are prone to label as terrorism all violent acts committed by their political opponents, while anti-government extremists frequently claim to be victims of government terror. (See Brian Michael 1978) The difficulty of defining terrorism has led to the notion, that, one man's terrorist is another man's freedom fighter. Terrorism, however, is characterized by the use of violence against civilians, with the expressed desire of causing terror or panic in the population.

Quoted in Charles kegley (1990) Christopher Joyner writes, "Politically, academically, and legally, the phenomenon of terrorism eludes clear and precise definition. In a real sense, terrorism is like pornography: You know it when you see it, but it is impossible to come up with a universally agreed-upon definition.

The hackneyed bromide “One man's terrorist is another man's freedom fighter" still remains a truism in international political perceptions. "Terrorism" lies in the eye of the beholder. Inability to arrive at a consensus about terrorism's characterization stems from the great variety of actors' 
motives, and practices that are associated with it. Nathanson (2010) posited that the main reason it has been difficult to define terrorism is political rather than theoretical.

Brian Berkey (2010) is of the view that there are four key elements of most philosophical definitions of terrorism. The first he called 'violence requirement', which limits terrorist acts to acts of violence. Second is the 'target criterion', which states that terrorist acts target individuals within a particular category, typically civilians, non combatants, or the innocent. The attack on Police Head Quarters Abuja Nigeria which was label terrorist attack may not be seen as such if we are to go by this second criterion. The third is the 'intention requirement' which has two parts. The first part requires that the violence inflicted on civilians, non combatant, or the innocent be intentionally inflicted on them, rather than, for example, inflicted on them as an unintended side effect of an attack on combatants. The second part requires the agent or agents inflicting the violence intend that their action cause fear or terror in others, in particular in those who identify in some way with the victims. The fourth and final element of typical definitions is the 'ideological goal requirement', which requires that the violence be inflicted, and the fear or terror created in hope of advancing a political, social or ideological goal. Almost all the definitions of terrorism contain one or more of the four elements listed above, yet a consensus definition has eluded scholars. The combination of these four elements still cannot be endorsed as valid definition of terrorism. It only gives us a picture of what terrorism is like. We shall attempt few definitions.

According to U. S. Department of Defense, terrorism is "the calculated use of violence or the threat of violence to inculcate 
The Morality of Suicide Terrorism and Boko Haram Challenges in Nigeria. - Chidiebere Obi \& Uchenna Azubuike Ezeogu

fear; intended to coerce or to intimidate governments or societies in the pursuit of goals that are generally political, religious, or ideological." For Walter Laqueur (1999), "Terrorism constitutes the illegitimate use of force to achieve a political objective when innocent people are targeted." In the view of C. J. M. Drake, "Terrorism is defined here as the recurrent use or threatened use of politically motivated and clandestinely organized violence, by a group whose aim is to influence a psychological target in order to make it behave in a way which the group desires." FBI defines terrorism as "The unlawful use of force or violence against persons, or property to intimidate or coerce a government, the civilian population, or any segment thereof, in furtherance of political or social objectives.

Michael Walzer's piece - Terrorism and Just War (2006), also brings to bear the fanatical parochialism that can dominate the terrorist psyche. He writes that - terrorists kill at random within a specific group of people. The message they deliver is directed at the group: we don't want you here. We will not accept you or make our peace with you as fellow-citizens or partners in any political project. You are not candidates for equality or even co-existence. This is most obviously the message of nationalistic terror, aimed at a rival nation, and of religious terror, aimed at infidels or heretics. Carl Wellman in Andrew Valls (2000) defines terrorism as, "the use or attempted use of terror as a means of coercion"

Terrorism can be in different forms, of which suicide terrorism is one. Suicide terrorism is the most aggressive form of terrorism. What distinguishes a suicide terrorist is that the attacker does not expect to survive a mission and often employs a method of attack that requires the attacker's death in 
order to succeed. The word "suicide" was first introduced in the 17 th century, said to be derived from the Latin words 'sui' (of oneself) and 'caedere' (to kill). Apparently, Sir Thomas Browne - a physician and a philosopher - was the first to coin the term suicide in his Religio Medici (1642) (See D. De Leo et al 2006). Suicide is the intentional killing of oneself. Intentionality has a great role in differentiating suicide from every other act. Cultural differences in the attitudes toward suicidal acts clearly question the adequacy of a universal definition. "Suicide is an act with a fatal outcome which the deceased, knowing or expecting a fatal outcome had initiated and carried out with the purpose of provoking the changes he desired" (WHO/EURO, 1986). "Suicide is a conscious act of self-induced annihilation, best understood as a multidimensional malaise in a needful individual who defines an issue for which suicide is perceived as the best solution" (Shneidman, 1985). Suicide is "death arising from an act inflicted upon oneself with the intention to kill oneself" (Rosenberg et al, 1988).

Suicide terrorism is that form of terrorism which involves individual self-sacrifice for the mission or attack to be successful. The Boko Haram situation in Nigeria represents a clear case of suicide terrorism. We will therefore consider the Boko Haram threat in Nigeria.

\section{The Boko Haram Challenge In Nigeria As Clear Case Of Suicide Terrorism}

Boko Haram is Nigeria militant Islamist group which means that western education is forbidden. It also calls itself, Jama'atu Ahlis Sunna Lidda'awati wal-jihad (translation: People Committed to the Propagation of the Prophet's Teachings and Jihad.) It was led by a certain Mohammed 
The Morality of Suicide Terrorism and Boko Haram Challenges in Nigeria. - Chidiebere Obi \& Uchenna Azubuike Ezeogu

Yusuf. From its etymology, Boko Haram is totally against western education- despite the fact that its leader and most of its members are products of western education. Boko Haram threatens the existential existence of the Nigerian state.

According to Akin Oyebode, Boko Haram emerged on the Nigerian landscape in 2002 when a group of young Islamic fundamentalists denounced the city of Maiduguri in North-east Nigeria as irredeemably corrupt and then moved to Kanama, a village in the neighbouring Yobe state, not too far from Niger, where they set up a separatist community based on rigid Islamic principles. From there, they started canvassing "true" Islamic law, anti-establishment ideologies, under its leader, Mohammed Ali who was later killed in a shootout with the military in December, 2003. They soon regrouped under a new leader, Mohammed Yusuf who recruited more members, largely from the Northern elite and jobless youths and refugees from Chad. They returned to Maiduguri and started building new structures, offering food, medicine and other benefits to the poor just like the Muslim Brotherhood in Egypt and other parts of the Middle East. The group had, more or less, become a state within a state with its own mosques, cabinet, religious police and farms. They now became known as "the Nigerian Taliban" and reportedly received financial support from Salafist elements in Saudi Arabia as well as wealthy Northern Nigerians.

It seems obvious that, the insurgent of Boko Haram in Nigeria is a product of government negligence. This negligence could be of two types: inattention to the group at its early stage, and lack of people oriented projects which could have kept the youths from violence. The resultant effect of this negligence has created what seems to be a big threat to the continuity of 
Nigeria as a nation. Boko Haram challenge in Nigeria remains a clear case of suicide terrorism, citing from its various attacks since inception. Boko Haram has claimed responsibility of various deadly attacks in Nigeria since 2009. This new wave of suicide terrorism is seen as a recent development in Nigeria.

James J. F. Forest(2012), in his article "Confronting the Terrorism of Boko Haram in Nigeria" listed the following cases of Boko Haram attacks:

- December 31, 2010: In the neighborhood of Jikowyi in Abuja city, unidentified militants detonated an improvised explosive device at the Dunamis Church.

- April 9, 2011: A polling center in Maiduguri was bombed by suspected members of Boko Haram.

- April 15, 2011: Members of the sect bombed the Independent National Electoral Commission headquarters in Niger state.

- May 29, 2011: On the day of President Goodluck Jonathan's inauguration, three bombs exploded within minutes of each other at an artillery brigades in Bauchi killing 13 people and injuring more than 40 others. Later that evening, another explosion occurred at a nearby drinking establishment in Shadawanka, killing six people.

- June 16, 2011: Boko Haram used a suicide car bomber to attack Nigeria's police headquarters (Louis Edet House) in Abuja. The explosion killed eight people, shattered the glass windows of the seven-story police headquarters and destroyed dozens of vehicles in the parking lot.

- July 22, 2011: An explosion at the Budun market - in Maiduguri, Borno state, injured three soldiers. 
The Morality of Suicide Terrorism and Boko Haram Challenges in Nigeria. - Chidiebere Obi \& Uchenna Azubuike Ezeogu

- July 23, 2011: A bomb exploded in Maidugri, close to the home of Abubakar Ibn Umar Garbai El-kanemi, the Shehu of Borno, leaving three soldiers wounded.

- August 2, 2011: A bomb exploded at Gomari Airport Ward in Maiduguri, killing at least one person.

- August 4, 2011: An explosion in Maiduguri killed two people.

- August 26, 2011: At least 18 people were killed in a suicide car bombing at the U.N. building in Abuja. The driver entered the compound by ramming an exit gate, and then maneuvered his vehicle into a parking garage before detonating it. This attack was Boko Haram's first attack against a transnational target rather than against a government or sectarian target.

- October 1, 2011: Attackers used explosives and gunfire to target an army patrol near a wedding in Maiduguri, killing three civilians.

- October 16, 2011: A bomb explosion killed three people at a police station in Gombe, northern Nigeria. Gombe Police Commissioner G.E. Orubebe said it was not clear who was behind the attack but it bore the hallmarks of similar strikes carried out by Boko Haram.

- January 20, 2012: Bomb attacks and shootings in Kano, Nigeria's second largest city killed 186 people in the group's most deadly attacks to date.

This is but a random selection of various attacks by the Boko Haram sect. Though, the sect has applied many methods of terrorist attacks, our focus remains on their 'suicide terrorism' method. Suicide terrorism raises a lot of moral questions, as the suicide terrorist is not like ordinary common criminal who knew the wrongness of his acts and therefore operates 
covertly. The willingness to kill or sacrifice one life has been a major issue of concern. We shall therefore consider the morality of suicide terrorism.

\section{The Morality Of Suicide Terrorism}

For scholars like Seto (2002), the question about the morality of terrorism is worth asking for three different reasons. First, that clear answer may persuade others to help us fight terrorism, and if we can articulate a compelling enough answer, we may even be able to dissuade potential terrorists themselves. Secondly, can the context in which terrorist acts arise ever justify such acts? If so, we must consider the possibility that a terrorist act by someone we do not like may be justified. Third, when we describe terrorism as immoral, one of our purpose is almost always to justify our own response. Implicitly, the question, is terrorism moral? Includes the mirror question, is our response to terrorism moral? Seto went further to state that terrorists typically believe that they are engaged in a righteous cause; they believe their acts are moral and justified. They are therefore quite unlike the ordinary criminal, who knows that what he is doing is wrong but does it anyway. But if terrorists believe that they are right, and we believe they are wrong, who then is correct. He went further to argue that, if terrorism is to make any claim to morality, it needs to include a communicative component. That is to say that the terrorists need to communicate their cause of distress, unfairness, ill-treatment, or injustice before taking any action. Blowing up a building without disclosing why is inherently gratuitous. It is also wrong to suggest that if Bin Laden had articulated his purposes, his action would have been moral. However, the failure to do so diminishes any claim to morality he might otherwise have had. 
The Morality of Suicide Terrorism and Boko Haram Challenges in Nigeria. - Chidiebere Obi \& Uchenna Azubuike Ezeogu

In the view of Howard Kainz (2003), when questions are raised about the morality of suicide bombing, justifications are given that these are acts of desperation by oppressed peoples, driven to extreme defensive measures. But is suicide terrorism the only option available to oppressed people? Have they exhausted every other option available? Kainz further assert that, there are supervening religious considerations, edicts and mandates by respected religious leaders who encourage and praise such acts as "martyrdom" leading to especially enticing heavenly rewards in the afterlife. And when confronted with the question of the murder of innocent noncombatants, the apologists for suicide bombing will often assert that in their special struggle, there are no "noncombatants." In the case of the Palestinian-Israeli conflict, the argument is that the enemy, Israel, is a militaristic country, completely mobilized, whose military "force" includes all males and females, young and old-all of whom perpetuate and assure, in various ways, according to their capacities, the oppression of Palestinians; even children are future combatants.

For Kainz, morality is considered irrelevant by those who feel they have a religious mandate to commit such acts, such as Islamist proponents of suicide bombing-including even many Muslim academicians. In a tradition like the modern Western tradition which recognizes the distinction between ethics and religion, and the distinction between politics and religion, an ethicist might get a hearing. But in the eyes of the strict Islamists who defend suicide bombing, there is no such distinction. Islamic law, sharia, is final.

Julian Madsen (2004) saw suicide terrorism as a weapon of the weak against a much stronger and superior enemy. Quoting Dr. Ramadan Shalah, Secretary-General of the Palestinian Islamic 
jihad, "Our enemy possesses the most sophisticated weapons in the world and its army is trained to a very high standard...We have nothing with which to repel the killing and thuggery against us except the weapon of martyrdom. It is easy and costs us only our lives... human bombs cannot be defeated, not even by nuclear bombs." The argument is that since, the weak cannot compete favorable with the more sophisticated opponent; it becomes rational for them to adopt the method of suicide terrorism in their struggle. Should morality and rationality be seen as identical? That an action is the most rational thing to be done at a particular time, does it make the act moral? Is reason the springboard of morality? If yes, how? And to what extent? If no, what then informs morality? This places us in a strong philosophical dilemma.

Jibey Asthappan (2010) opined that human's natural survival instinct would prohibit a person from putting himself in danger, but exception to this human drive may explain why terrorists logically kill others and themselves. Quoting Ferracuti (1982) Asthappan, went further to assert that, death per se cannot be accepted at the experimental level and must therefore be rationalized as a religious transition from life on earth to eternal life. Enders and Sandler (2006) argue that even suicide bombers are rational if "the utility obtained from living with the current state of affairs is less than that obtained by a life-ending action"

\section{Evaluation and Conclusion}

From the foregoing argument on the relationship between rationality and morality, one could attempt to solve the philosophical puzzle by saying that rationality does not determine the goodness of an act because one can be a rational agent but could choose to perform a bad act. Morality could be 
The Morality of Suicide Terrorism and Boko Haram Challenges in Nigeria. - Chidiebere Obi \& Uchenna Azubuike Ezeogu

defined as social standards for good or bad character or behaviour. We can only talk about the morality of an action if the act is performed by a rational being but logically speaking, a rational being does not necessarily presuppose a being that performs good act (this is because he can as well perform bad acts). Having established in the course of this work that a suicide bomber is a rational being, then, it means that his act could be adjudged bad if having considered the circumstances, conditions and intention that propelled his act or otherwise good.

Furthermore, the above definition of morality as social standards for good and bad character has introduce some elements of relativism to the concept of morality because an Islamic cleric who indoctrinates the potential suicide bombers on the noble and heroic reward of the act of suicide terrorism is also setting up a morality that should guide them. But does it mean that morality is relative? The possible answer to the question is that there is relativity in universality in the concept of morality. This is because we have a universal moral law but its application varies from society to society. For instance, the law "thou shall not kill" is relative in its application because we have instances where one is permitted to kill (e.g. Self defense). Could suicide terrorism be one of these instances?

The answer to the above question could be positive or negative depending on the outcome of the consideration of the factors that qualify an action to be good or bad which include: circumstance, condition and intention. This is because 'self defense' is morally justifiable because of these factors. Going by this, Boko-Haram threat in Nigeria should not be condemned out rightly without first understanding these factors i.e. the circumstances surrounding the Boko-Haram attacks, condition of these attacks and the intention of these 
attackers. This can as well facilitate the amelioration of this challenge facing us.

The lousy excuses that the perpetrators of these attacks are faceless should be regarded as a very big inefficiency of the government and her security agencies. Experience has thought us that terrorists are not faceless but can be apprehended and their attacks avoided.

This paper also condemns the proposed amnesty to the BokoHaram sect by the Federal Government. First of all, this, we must say, is a contradiction on the side of the government by trying to give amnesty to a group it named faceless and secondly, giving money as an amnesty to a terrorist group without tackling the root cause of their insurgency is a fundamental mistake that has the possibility of making the group stronger or making the group a role model for other aspiring terrorists.

This paper suggests that the government should take a swift action by using prudent means to unravel the moral question of the circumstances, conditions and intentions of the BokoHaram terrorist threat before devising a means of solving or stopping the threat.

\section{References}

Andrew Valls, "Can Terrorism Be Justified?" Ethics In International Affairs, Andrew Valls ed. Rowman \& Littlefield, (2000)

Akin Oyebode, Legal Responses To Boko Haram Challenge:

An Assessment Of Nigeria's Terrorism (Prevention) Act, 2011, Forum On Public Policy

Brian Berkey, 'Terrorism and Moral Distinctiveness' Berkeley - London Graduate Philosophy Conference (2010) 
The Morality of Suicide Terrorism and Boko Haram Challenges in Nigeria. - Chidiebere Obi \& Uchenna Azubuike Ezeogu

Brian Michael, "The Study of Terrorism: Definitional Problems", Institute of Management Sciences and Operations Research Society of America, New York (1978).

Charles Kegley, "The Characteristics of Contemporary International Terrorism," in

Charles Kegley, ed., International Terrorism New York: St. Martin's (1990)

De Leo, D. et al "Definitions of Suicidal Behavior" Crisis vol. 27 (1) Hogrefe \& Huber Publishers (2006)

Enders, W. and T. Sandler. The political economy of terrorism, New York: Cambridge University Press (2006)

Howard Kainz, "Suicide Bombing: A Challenge To Just-War Theory And Natural Law" Human Rights Review, volume 5, no. 1 (October 2003)

James J. F. Forest, "Confronting the Terrorism of Boko Haram in Nigeria" Joint Special Operation University Report JSOU Press MacDill Air Force Base Florida 2012.

Jibey Asthappan, "The Effectiveness of Suicide Terrorism" Journal of the Washington Institute of China Studies Vol. 5 No. 1 (2010)John Horgan, The Psychology Of Terrorism. London: Routledge (2005)

Julian Madson, "Suicide Terrorism: Rationalizing the Irrational", Strategic Insights, Volume III, Issue 8 (August 2004)

Michael Walzer, -Terrorism and Just War, Philosophia 34, (2006) 
Rosenberg, M.L., et al "Operational criteria for the determination of suicide". Journal of Forensic Sciences, 33 (1988)

Shneidman, E.S. Definition of Suicide. New Jersey: Jason Aronson Incorporated (1985)

Stephen Nathanson Terrorism And The Ethics Of War Cambridge: Cambridge University Press (2010)

Theodore P. Seto, The Morality Of Terrorism, 35 Loy. L. A. L. Rev. 1227 (2002) available at http://digitalcommons.imu.edu/llr/vol35/issu4/4

Valarie Thomson, Boko Haram and Islamic Fundamentalism in Nigeria

Global Security Studies, summer, Volume 3, Issue 32012.

Walter Laqueur, The New Terrorism: Fanaticism and the Arms of Mass Destruction. New York: Oxford University Press, (1999).

Zuleyka Zevallos, "What Would Durkheim say? Altruistic suicide in Analyses of Suicide Terrorism" TASA Conference, University of Western Australia \& Murdoch University, (2006) 